\title{
In Vitro Evaluation of Botanical Extracts, Chemical Fungicides and Trichoderma harzianum Against Alternaria brassicicola Causing Leaf Spot of Cabbage
}

\author{
Lok Bahadur Pun ${ }^{1}$, Kamal Chhetri ${ }^{1}$, Anju Pandey ${ }^{2}$ and Rajan Paudel* \\ ${ }^{1}$ Department of Horticulture and Plant Protection, TribhuvanUniversity, IAAS Lamjung Campus \\ ${ }^{2}$ Department of Horticulture and Plant Protection, Tribhuvan University, IAAS Paklihawa Campus \\ Corresponding author's email: rajan@iaas.edu.np
}

Received on: 8 August 2019, Revised on: 23 December 2019, Accepted on: 4 January 2020

\begin{abstract}
Alternaria leaf spot caused by Alternaria brassicicola is one of the destructive diseases of crucifers and causes considerable loss in the yield and qualityof the produce. An experiment was conducted in in vitro to evaluate the efficacy of six botanical extracts at three concentrations i.e. $5 \%, 10 \%$ and $15 \%$, six chemical fungicides at five different concentrations i.e. 50ppm, 100ppm, 250ppm, 500ppm and 1000ppm and Trichoderma harzianum against Alternaria brassicicola.The study was carried out using poisoned food technique for botanical extracts and chemical fungicides and dual culture technique for T. harzianum in Completely Randomized Design (CRD). Among botanical extracts, maximum inhibition (99.91\%) of mycelial growth was observed in sweet flag at $15 \%$ concentration followed by $10 \%$ sweet flag $(96.68 \%)$ and 5\% sweet flag (93.64\%) and minimum inhibition percent (5.61\%) was observed in Lantana camara at $5 \%$ concentration. Hexaconazole proved to be the most effective chemical fungicide recording $100 \%$ growth inhibition at all the tested concentrations which was at par with $1000 \mathrm{ppm}$ metalaxyl + mancozeb (Kriloxyl Gold), 500 and 1000 ppm mancozeb and 1000 ppm carbendazim + mancozeb(SAAF)whereas, $50 \mathrm{ppm}$ carbendazim was least effective in reducing fungal growth (7.16\%). T. harzianum showed $65.02 \%$ inhibition of test fungus. The study indicated better performance of some chemical fungicides even at lower concentrations i.e. $100 \mathrm{ppm}$ and $250 \mathrm{ppm}$. So, such effective fungicides could be used to minimize hazardous effect. Significant effect of some botanical extracts against pathogen growth suggests their application as potential control agent alternative to chemicals.
\end{abstract}

Keywords: Alternaria, fungicides, plant extracts, poisoned food technique, Trichoderma

\section{Introduction}

Cabbage (Brassica oleraceae var. capitata L.) is a leafy head vegetable belonging to Brassicaceae(Cruciferae) family. It is grouped as cole crops, which is originated from a single wild species Brassica oleracea var. oleracea (sylvestrisL.), commonly known as wild cabbage or 'Colewort' (Balliu, 2014). Cabbage is native of Western Europe and the northern shore of Mediterranean region (Bose et al. 2001). It grows well in relatively cool, moist climate with moderate to heavy rainfall. It can stand frost in head stage, but freezing temperatures are destructive in other stages. The optimum temperature for seed germination is 12$16^{\circ} \mathrm{C}$ and for growth and heading is $15-20{ }^{\circ} \mathrm{C}$, while the growth is arrested above $25^{\circ} \mathrm{C}$ (Singh, 2007). It is 
biennial crop but grown as annual for vegetable and requires cold treatment for flowering.

Global production of cabbage and other brassicas in 2017 was 71,451,138 $\mathrm{mt}$ and the area harvested was 2,513,707 ha (Food and Agriculture Organization Corporate Statistical Database [FAOSTAT], 2019). China ranks first in production (33.42 million $\mathrm{mt}$ ) followed by India ( 8.807 million $\mathrm{mt}$ ) and Russia (3.53 million $\mathrm{mt}$ ). In Nepal the area cultivated is 29,373 ha and the production is 485,199 $\mathrm{mt}$ (Ministry of Agriculture and Livestock Development [MOAD], 2016/17).

Several biotic and abiotic stress affects on its production. Within the biotic stress, Alternaria leaf spot is a common disease incited by several species of Alternaria. In cabbage it is caused mainly by two species i.e. Alternaria brassicae (Berk.) Sacc., and $A$. brassicicola (Schweintiz) Wiltshire. Symptoms may first develop on young plants in seedbeds, where leaf spots, stunting or damping off may occur. Leaf spots incited by $A$. brassicicola appears as small, dark colored spots which spread rapidly to form circular lesions up to $1 \mathrm{~cm}$ in diameter (Singh, 1998). Alternating light and dark concentric rings give the spots the appearance of target; a yellow halo may surround the lesion. The spot incited by large-spore form, A.brassicae shows much common symtoms compared to A. brassicicola and tend to remain larger and lighter in colour. The fungus is primarily seed-borne, but can also come from crop residue. Spores are spread by wind, water splash, human, agricultural tools and equipments. They can also survive in susceptible weeds or perennial crops (Mamgain et al.,2013). Under in vitro conditions sporulation of $A$. brassicae occurs at optimum temperature of $18-24^{\circ}$ $\mathrm{C}$ and $A$. brassicicola at $20-30^{\circ} \mathrm{C}$. Yield losses due to Alternaria infection have been reported to be $10-70 \%$ in India (Singh et al. 2017; Choudhary et al., 2018) and $32-57 \%$ in Nepal (Shrestha et al., 2005; Saharan, et. al., 2016). The disease infect foliage causing extensive damage to tissue involved in photosynthesis and hence result in yield loss.

Conventionally, different fungicides are used for controlling this disease. Indiscriminate use of higher dose of chemical fungicidesaffect environment and human health but also increase input cost (Ahmad \& Ashraf, 2016). Several medicinal and aromatic plants show antioxidant and antifungal properties which not only reduce disease development but also produce harmful residue free products (Kavita\&Dalbeer, 2015). Use of plant extracts is considered as cost effective and eco-friendly approach of disease management, without any environmental pollution (Khalse et al., 2017). So, the present study was undertaken to screen the effective chemical fungicides and botanical extractswith their optimum concentration and to determine biocontrol potentiality of Trichoderma harzianum against Alternaria brassicicola.

\section{Materials And Methods}

The experiment was carried out in Plant Pathology Laboratory ofInstitute ofAgriculture andAnimalScience (IAAS), Lamjung in Completely Randomized Design using poisoned food technique (Nene \&Thapliyal, 1979; Thaware,Fugro, Jadhav, Magar\&Karande, 2010; Roopa,Yadahalli\&Kavyashree, 2014) for botanicals and fungicides screening. Five chemical fungicides i.e. mancozeb, copper oxychloride, hexaconazole, carbendazim + mancozeb and metalaxyl + mancozeb were evaluated at five different concentrations such as 50, 100, 250, 500 and 1000 ppm whereas carbendazim was evaluated at four concentrations i.e. 50, 250, 500 and $1000 \mathrm{ppm}$ and six botanical extracts (i.e. neem leaf, garlic bulb, ginger rhizome, Lantana camara leaf, sweet flag rhizome and Artemisia vulgaris leaf) were evaluated at three different concentrations viz. $5 \%, 10 \%$ and $15 \%$ respectively. Biocontrol potentiality of $T$. harzianumwas studied using dual culture technique(Babu et al.,2000). Each of the treatment was replicated three times.

\section{Isolation and maintenance of pure culture}

Pathogenic Alternaria brassicicola was isolated from infected leaf of cabbage collected from field of IAAS, Lamjung. Spores were teased from infected portion for microscopic examination to check the presence of pathogenic fungus. After confirming the presence of Alternaria brassicicola, leaves were cut into small pieces $(1-1.5 \mathrm{~cm})$ with sterile blade. These pieces were disinfected with $0.5 \%$ sodium hypochlorite $(\mathrm{NaOCl})$ solution for two minutes followed by three washings with distilled water and excessive moisture was removed using sterile blotting paper. The sterilized leaf pieces were placed on PDA medium using sterilized forceps and incubated at $271^{\circ} \mathrm{C}$ for 7 days. On the basis of morphological characters of conidia as described by 
Yu (2015); Corlett and MacLatchy, (1996a, 1996b) pathogen was identified as Alternaria brassicicola. Culture was purified by transferring small piece of agar containing spore to another petri plate containing media and incubated at $271^{\circ} \mathrm{C}$ for 7 days. The pathogen was sub cultured three times to obtain pure culture and pure culture thus obtained was preserved in PDA slant at $4^{\circ} \mathrm{C}$.

\section{In vitro evaluation of botanical extracts and chemical fungicides}

Botanical extract was prepared as per methods used by Ul-Haqet al., (2014) and Thaware et al., (2010). Fresh and healthy leaves, bulbs and rhizomes were collected, thoroughly washed in tap water followed by sterilized distilled water, then air dried and grounded with mortar and pestle with the addition of distilled water at the ratio of $1: 1 \mathrm{w} / \mathrm{v}$. Then the extract obtained was filtered through double layered muslin cloth. Extract was centrifuged at $4000 \mathrm{rpm}$ for 5 minutes. The supernatant was then filtered through Whatman's filter paper No. 1 and then .boiled at $80^{\circ} \mathrm{C}$ for 10 minutes in a hot water bath. Thus obtained filtrate was taken as $100 \%$ basic stock solution. After autoclaving PDA media and cooling it to $50^{\circ} \mathrm{C}$ required amount of this standard solution was mixed into PDA to get final concentration of $5 \%, 10 \%$ and $15 \%$ for poisoned food technique. Similarly for the evaluation of chemical fungicides, calculated amount of stock solution was mixed in sterilized PDA to make final concentration of 50ppm, 100ppm, 250ppm, 500ppm and 1000ppm. Twenty $\mathrm{ml}$ of amended PDA was poured in each $90 \mathrm{~mm}$ sterilized petri plate and allowed to solidify. Control treatment was maintained without adding plant extracts or chemical fungicides on PDA. A circular disc of $7 \mathrm{~mm}$ diameter from 9 days old culture of Alternaria brassicicola was cut with sterilized cork borer and inoculated in the centre of solidified amended as well as control media. Each treatment was replicated in three petri plates. Then the petriplates were incubated at 27 $1{ }^{\circ} \mathrm{C}$ for seven days.

\section{Dual culture method}

The antagonistic activity of Trichoderma harzianumobtained from Nepal Agriculture Research Council (NARC), Khumaltarwas tested against Alternaria brassicicola in in vitrocondition using dual culture technique. Twenty $\mathrm{ml}$ of PDA was poured into sterile petri plates. A $7 \mathrm{~mm}$ mycelial disc of actively growing Alternariawas placed on one end of a petri plate at $1 \mathrm{~cm}$ away from the edge. Similarly, $7 \mathrm{~mm}$ mycelial disc from 7 days old culture of $T$. harzianum was placed on opposite end of petri plate at $1 \mathrm{~cm}$ away from edge. Plates inoculated with pathogen without biocontrol agent served as a control. Each treatments was replicated in three petri plates. Then the plates were incubated at $27 \pm 1^{\circ} \mathrm{C}$ for 7 days.

\section{Growth inhibition test}

The observation on mycelial growth was recorded after 7 days of incubation in each treatment using vernier caliper scale. The percent growth inhibition of mycelial growth over control was calculated by using the formula given by Vincent (1947, as cited in Kantwa et al., (2014); Roopa et. al, 2014).

$$
\mathrm{PGI}=\frac{(\mathrm{C}-\mathrm{T})}{\mathrm{C}} \times 100
$$

Where, $\mathrm{PGI}=$ Percent growth inhibition, $\mathrm{C}=$ Growth of hyphae in control ( $\mathrm{mm})$ and

$\mathrm{T}=$ Growth of hyphae in treatment $(\mathrm{mm})$

\section{Statistical analysis}

All the data were entered in MS Excel (2013) and analysis of variance was done using RStat software (version 3.5.3). Mean comparison was done using Fisher-LSD test at 0.05 level of significance.

\section{Results And Discussion}

\section{In vitro evaluation of botanical extracts}

Six different botanical extracts were evaluated at three concentrations for their efficacy against Alternaria brassicicola in vitro. The result revealed that, all the tested botanicals inhibited the growth of pathogen over untreated control. Extracts from different plant species used in the experiment showedto possess different level of fungicidal effect against test fungus. Growth inhibition ranged from $32.53 \%$ to $96.74 \%$ irrespective of concentrations. Significant difference $(P<0.001)$ was obtained among different botanical extracts in their inhibition effect. Increase in effectiveness was observed with increase in concentration. Among three concentrations used, maximum reduction of mycelial growth $(74.84 \%)$ was observed at $15 \%$ 
concentrationwhich wassignificantly superior over rest of concentrations. Among the botanical extracts, maximum mean growth inhibition (96.74\%) of tested pathogen was recorded in sweet flag followed by neem $(77.34 \%)$ and garlic $(70.05 \%)$ while, minimum growth inhibition $(32.53 \%)$ was recorded in Lantana camara followed by Artemisia vulgaris (46.77\%). In case of interaction effect all concentrations i.e. $5 \%, 10 \%$ and $15 \%$ of sweet flag proved to be superior with highest inhibition effect of $93.64 \%, 96.68 \%$ and $99.91 \%$ respectively. This was followed by all concentrations $(5 \%, 10 \%$ and $15 \%)$ of neem $(75.87 \%, 76.00 \%$ and $80.15 \%)$ and $15 \%$ of garlic extract $(77.34 \%)$ which were statistically at par with each other. Lantana camara at 5\% concentration showed minimum mycelial growth inhibition of $5.61 \%$ followed by Artemisia vulgaris at $5 \%(19.82 \%)$, Lantana camara at 10\% (24.68\%) and ginger at $5 \%(49.72 \%)$.

\begin{tabular}{|c|c|c|c|c|c|c|c|c|}
\hline \multirow[b]{3}{*}{$\begin{array}{l}\text { S. } \\
\text { N. }\end{array}$} & \multirow[b]{3}{*}{ Treatments } & \multicolumn{6}{|c|}{ Concentrations } & \multirow{3}{*}{$\begin{array}{c}\text { Mean } \\
\text { Growth } \\
\text { Inhibition } \\
(\%)\end{array}$} \\
\hline & & $5 \%$ & & $10 \%$ & & $15 \%$ & & \\
\hline & & $\begin{array}{c}\text { Mean } \\
\text { colony } \\
\text { diameter } \\
(\mathbf{m m})\end{array}$ & $\begin{array}{c}\text { Growth } \\
\text { inhibition } \\
(\%)\end{array}$ & $\begin{array}{c}\text { Mean } \\
\text { colony } \\
\text { diameter } \\
(\mathbf{m m})\end{array}$ & $\begin{array}{c}\text { Growth } \\
\text { inhibition } \\
(\%)\end{array}$ & $\begin{array}{c}\text { Mean } \\
\text { colony } \\
\text { diameter } \\
(\mathbf{m m})\end{array}$ & $\begin{array}{c}\text { Growth } \\
\text { inhibition } \\
(\%)\end{array}$ & \\
\hline 1 & $\begin{array}{l}\text { Neem } \\
\text { (Azadirachtaindica) }\end{array}$ & 12.84 & 75.87 & 12.77 & 76.00 & 10.57 & 80.15 & 77.34 \\
\hline 2 & $\begin{array}{l}\text { Garlic (Allium } \\
\text { sativum) }\end{array}$ & 18.17 & 65.85 & 17.58 & 66.97 & 12.06 & 77.34 & 70.05 \\
\hline 3 & $\begin{array}{l}\text { Ginger } \\
\text { (Zingiberofficinale) }\end{array}$ & 26.76 & 49.72 & 19.27 & 63.79 & 20.66 & 61.18 & 58.23 \\
\hline 4 & $\begin{array}{l}\text { Sweet flag } \\
\text { (Acoruscalamus) }\end{array}$ & 3.39 & 93.64 & 1.77 & 96.68 & 0.05 & 99.91 & 96.74 \\
\hline 5 & $\begin{array}{l}\text { Wild sage (Lantana } \\
\text { camara) }\end{array}$ & 50.23 & 5.61 & 40.08 & 24.68 & 17.41 & 67.29 & 32.53 \\
\hline 6 & $\begin{array}{l}\text { Mugwort } \\
\text { (Artemisia vulgaris) }\end{array}$ & 42.67 & 19.82 & 22.71 & 57.31 & 19.61 & 63.16 & 46.77 \\
\hline 7 & Control & 53.22 & --------- & 53.22 & -------- & 53.22 & --------- & 0.00 \\
\hline & $\begin{array}{l}\text { Mean } \\
\text { CV }(\%) \\
\operatorname{SEM}( \pm) \\
\operatorname{LSD}(p=0.05)\end{array}$ & & $\begin{array}{l}51.75 \\
7.69 \\
2.30 \\
7.08\end{array}$ & & $\begin{array}{l}64.24 \\
4.54 \\
1.68 \\
5.19\end{array}$ & & $\begin{array}{l}74.84 \\
5.49 \\
2.374 \\
7.32\end{array}$ & \\
\hline
\end{tabular}

CV: Coefficient of Variation SEM: Standard Error of Mean LSD: Least Significant Difference

The result was in confirmatory to finding of Pitipong, (2009) who reported complete inhibition of Alternariasp. in A. calamusat $1 \% \mathrm{v} / \mathrm{v}$. Growth of Alternariasp. was completely inhibited above $0.10 \%$ concentrations of A. calamus (Mungkornasawakul et al., 2002). Sadana\&Didwania, (2015) obtained 73.7\% inhibition in $15 \%$ neem against $A$. solani. Similarly, Kavita and Dalbeer (2015), Waghe et al., (2015), Kakraliya et al., (2018) revealed significant inhibition effect of neem. Chethana et al., (2012), Thaware et al., (2010) and
Kantwa et al., (2014) reported better performance of garlic among tested extacts against Alternaria sp.The result was in contrary with result of Shrestha and Tiwari, (2009); Biswas and Gosh, (2018). This might be due to inherent physiological differences in different Alternaria species. Variation in antifungal activity of different botanicals is due to variation in the content of active antifungal chemicals in the extracts (Shrestha \& Tiwari, 2009). Antifungal activity of sweet flag is due to the presence of $\alpha$ - and $\beta$-asarone in leaves and rhizomes 
(Devi et al., 2014). Scanning electron microscopic study have shown that hyphae and conidia treated with Acorus fraction were shrunken and collapsed, which might be due to fluid leakage and some alteration in the membrane permeability (Phongpaichit et al., 2005). Singh et al., (2011) mentioned that, antifungal activity of neem is due to presence of several triterpenoids, peaks and pure compounds (isomeldenin and nimonol) )and also Quercetin and $\beta$-sitosterol. In addition to these 6-deacetylnimbin, azadiradione, salannin and epoxyazadiradione are other active compounds. According to Lyer and Williamson, (1991) antifungal properties of neem extracts is attributed to inhibition of protease

\section{Fungicides}

\begin{tabular}{|c|c|c|c|c|c|c|c|c|c|c|c|c|}
\hline \multirow[t]{2}{*}{$\begin{array}{l}\text { S. } \\
\text { N. }\end{array}$} & \multirow[t]{2}{*}{ Treatments } & \multicolumn{5}{|c|}{$\begin{array}{l}\text { Mean colony diameter ( } \mathrm{mm}) \text { at } \\
\text { different concentrations (ppm) }\end{array}$} & \multicolumn{5}{|c|}{$\begin{array}{c}\text { Growth inhibition }(\%) \text { at different } \\
\text { concentrations (ppm) }\end{array}$} & \multirow{2}{*}{$\begin{array}{c}\text { Mean } \\
\text { Growth } \\
\text { Inhibition } \\
(\%)\end{array}$} \\
\hline & & 50 & 100 & 250 & 500 & 1000 & 50 & 100 & 250 & 500 & 1000 & \\
\hline 1 & Hexaconazole & 0 & 0 & 0 & 0 & 0 & 100 & 100 & 100 & 100 & 100 & 100 \\
\hline 2 & Mancozeb & 22.51 & 15.84 & 0.84 & 0 & 0 & 68.57 & 77.87 & 98.83 & 100 & 100 & 89.05 \\
\hline 3 & Carbendazim & 66.46 & ----- & 53.28 & 52.99 & 44.53 & 7.16 & ----- & 25.58 & 25.97 & 37.80 & 27.84 \\
\hline 4 & $\begin{array}{l}\text { Copper } \\
\text { Oxychloride }\end{array}$ & 43.43 & 35.77 & 10.91 & 4.94 & 4.99 & 39.33 & 50.4 & 84.76 & 93.10 & 93.04 & 72.05 \\
\hline 5 & $\begin{array}{l}\text { Carbendazim }+ \\
\text { Mancozeb }\end{array}$ & 9.05 & 6.67 & 3.89 & 2.35 & 0.20 & 87.36 & 90.69 & 94.56 & 96.72 & 99.72 & 93.81 \\
\hline 6 & $\begin{array}{l}\text { Metalaxyl + } \\
\text { Mancozeb }\end{array}$ & 18.54 & 13.53 & 4.09 & 3.05 & 0 & 74.10 & 81.10 & 94.28 & 95.74 & 100 & 89.05 \\
\hline \multirow[t]{2}{*}{7} & Control & \multicolumn{5}{|c|}{71.59} & \multicolumn{5}{|l|}{0.00} & 0.00 \\
\hline & $\begin{array}{l}\text { Mean } \\
\operatorname{CV}(\%) \\
\operatorname{SEM}( \pm) \\
\operatorname{LSD}(p=0.05)\end{array}$ & & & & & & $\begin{array}{l}62.75 \\
6.66 \\
2.415 \\
7.44\end{array}$ & $\begin{array}{l}79.94 \\
7.07 \\
3.26 \\
10.28\end{array}$ & $\begin{array}{l}83.00 \\
3.58 \\
1.715 \\
5.29\end{array}$ & $\begin{array}{l}85.26 \\
2.63 \\
1.293 \\
3.98\end{array}$ & $\begin{array}{l}88.43 \\
2.26 \\
1.153 \\
3.55\end{array}$ & \\
\hline
\end{tabular}

CV: Coefficient of Variation; SEM: Standard Error of Mean; LSD: Least Significant Difference

The efficacy of different chemical fungicides against test fungus was evaluated in vitro using poisoned food technique. The data on inhibition percent is presented in table 2. An insight into data reveals that all the tested chemical fungicides showed significant effect $(\mathrm{P}<0.001)$ against pathogen growth over control $(71.59 \mathrm{~mm})$. The extent of mycelial growth inhibition increased with increase in their concentration. Among the chemicals tested hexaconazole proved to be the most effective fungicide showing complete inhibition (100\%) followed by carbendazim + mancozeb $(93.81 \%)$ activity. Inhibition in growth of fungus is due to change in hydrophobicity of cells causing anti-adhesion (Polaquini et al.,2006). Allicin is a key antifungal compound present in garlic and there is presence of phenolics, alkaloids, flavonoids, steroids, glycosides, saponins and tannins (Akinmusire et al.,2014). The effectiveness of garlic clove extract is due to volatile oil which contains dialyldisulphide, diallyltrisulphide and sulphodioxides derived from allicin (Chethana et al.,2012). The allicin or ajoene restricts the performance some enzymes that are important to fungi (Kutawa et al, 2018).

\section{In Vitro Evaluation of Chemical}


$(94.56 \%)$ and metalaxyl + mancozeb (94.58\%). Minimum growth inhibition $(7.16 \%, 25.58 \%, 25.97 \%$ and $37.80 \%$ ) were obtained in all tested concentrations $(50,250,500$ and $1000 \mathrm{ppm})$ of carbendazim followed by 50 ppm copper oxychloride (39.33\%).

Similar result was recorded in findings of Panwar et al., (2013) who reported complete growth inhibition of $A$. alternata in hexaconazole followed by mancozeb and least inhibition in carbendazim. Similarly, Tu (2015) recorded complete inhibition of $A$. brassicicola by hexaconazole, mancozeb at 250, 500 and $1000 \mathrm{ppm}$ and by metalaxyl + mancozeb at 500 and $1000 \mathrm{ppm}$ and least inhibition at carbendazim. Roopa,Yadahalli and Kavyashree (2014) found mancozeb as a superior contact fungicide, hexaconazole as a superior systemic fungicide and carbendazim +mancozeb as superior combination fungicide against $A$. solani. Biswas and Ghosh (2018), Kantwa et al., (2014) obtained significant growth inhibition effect of Alternaria sp. in mancozeb. Similar inhibition was observed by Thawareet al., (2010) against $A$. alternata.Gautam et al., (2018) reported $93.65 \%, 87.65 \%$ and $76.7 \%$ growth inhibition of $A$. brassicae at $0.1,0.01$ and $0.001 \%$ concentrations of SAAF (carbendazim + mancozeb) respectively. SAAF effectively controlled the Alternaria blight of sunflower in field experiment of Wagheet al., (2015). Synthetic fungicides bring about the inhibition of pathogens either by destroying theircell membrane or its permeability or by inhibiting metabolic processes of the pathogen and hence are effective (Kakraliya et al., 2018). Higher inhibition effect of hexaconazole is due to inhibition of ergosterol biosynthesis, controlling the growth and reproduction of fungal pathogen (Muhamad et al., 2010). Mancozeb being multisite inhibitor effects lipid metabolism, respiration and production of ATP, it interferes with enzymes containing sulphydryl groups, disrupting different biochemical process within the fungal cell cytoplasm and mitochondria.

\section{In Vitro evaluation of Trichoderma harzianum against Alternaria brassicicola.}

In this study, the antagonistic effect of $T$. harzianum was assessed against Alternaia brassicicola using dual culture technique. Growth inhibition by $65.02 \%$ of Alternaria spp. was obtained after seven days of incubation as compared to control. The result is in agreement with Ganie et al., (2013), who reported
$71.85 \%$ growth inhibition of $A$. solani. Such inhibitory effect of $T$. harzianum have been recorded by Wagheet al., (2015) and Kulkarni et al., (2014). The antagonistic activity of Trichoderma is mainly due to production of acetaldehyde compound (Kithan\&Daiho, 2014). Nutrients and niche competitions, antibiosis by production of volatile components and non-volatile antibiotics could be possible cause of antagonism (Hajieghrari et al., 2008; Kumar et al., 2011). Inhibitory activity of Trichoderma spp. may be due to secretion of extracellular cell degrading enzymes such as chitinase, B-1,3-glucanase, cellulose, lectin (Kakraliyaet al., 2018) and other secondary metabolites such as glioviridin, viridian and gliotoxin which may help mycoparasites in colonization of host (Patel, Lal and Singh, 2014).

\section{Conclusion}

Alternaria leaf spot is a worldwide disease of economic importance in brassica vegetables. Different chemical fungicides are commercially available in market to control this disease. This study revealed significant inhibition effect of all the tested chemical fungicides and botanical extracts over control. Indiscriminate application of chemical fungicides have resulted several health hazards, negative impacts in environment so, the use of effective chemical at possible lower concentrations could be safer way to minimize health hazards and environmental pollutions. T. harzianum and botanical extracts such as sweet flag, neem and garlic exhibited inhibition of Alternaria brassicicola at higher percentage. Therefore, this biological agent and plant extracts could be a potential to be used as novel fungicides alternative to harmful chemical fungicides. However, these in vitro research finding should be verified in the field conditions before taking for field application.

\section{Acknowledgement}

Authors are thankful to Mr. Ram Kumar Shrestha, Asst. Professor, Institute of Agriculture and Animal Science (IAAS), Lamjung for his continuous support and guidance, IAAS (Lamjung) for providing required materials and equipments and Plant Pathology Division, NARC (Khumaltar) for providing culture of T. harzianum. 


\section{References}

Ahmad, A. \&Ashraf, Y. (2016). In vitro andin vivo management of Alternarialeaf spot of Brassica campestrisL. Journal of Plant Pathology and Microbiology 7, 7. doi: 10.4172/21577471.1000365

Akinmusire, O. O., Omomowo, I. O. \& Usman, I. M. (2014). Evaluation of the phytochemical properties and antifungal activities of ethanol extract of Allium sativum. International Journal of Current Microbiology and Applied Sciences, 3(10), 143-149

Babu, S., Seetharaman, K., Nandakumar, R.\& Johnson, I. (2000). Efficacy of fungal antagonists against leaf blight of tomato caused by Alternaria solani(Ell, and Mart.). Journal of Biological Control, 14(2), 79-81.

Balliu, A. (2014). Cabbage. In K. V. Peter and P. Hazra (Eds), Handbook of Vegetables, 3, 79-120.

Biswas, M.K. \& Ghosh, T. (2018). Evaluation of phytoextracts, biological agents and chemicals against the devlopment of Alternaria brassicae in vitro and vivo. European Journal of Medicinal Plants, 22(9), 1-9

Bose, T.K., Kabir, J.,Das, P. \&Joy P.P. (Eds). (2001). C.Tropical Horticulture. Calcutta: NayaProkash 206 BidhanSarani.

CHEBI: 81766-hexaconazole. (n.d.). Retrieved from https://www.ebi.ac.uk/chebi/searchId. do? chebiId $=$ CHEBI $: 81766$

Chethana, B. S., Ganeshan, G.,Rao, A. S. \&Bellishree, K. (2012). In vitro evaluation of plant extracts, bioagents and fungicides against Alternariaporri(Ellis) Cif., causing purple blotch disease of onion. Pest Management in Horticultural Ecosystems, 18(2), 194-198.

Choudhary, C. S., Mishra, A. K., Singh, R. S.,Mukherjee, U. \&Pandey, A. (2018). Management of alternaria blight of Indian mustard in Bihar. International Journal of Current Microbiology and Applied Sciences, (7), 1053-1058.Retrieved from https://www.ijcmas.com/special/7/ C.S.\%20Choudhary,\%20et\%20al.pdf

Corlett, M. \&MacLatchy, L. A. (1996). Alternaria brassicae. Canadian Journal of Plant Pathology, 18(4), 482-483. doi: 10.1080/07060669609500608.
Corlett, M.\&MacLatchy, L. A. (1996). Alternaria brassicicola. Canadian Journal of Plant Pathology, 18(4), 484-485. doi: 10.1080/07060669609500609.

Couch, H. B. \& Smith, B. D. (n.d.). Synergistic and antagonistic interactions of fungicides against Pythium aphanidermatum on ryegrass. State University, Blacksburg, Viginia

Devi, A. S., Bawankar, R. \&Babu, S. (2014). Current status on biological activities of Acorus calamus-a review. International Journal of Pharmacy and Pharmaceutical Sciences, 6(10)

FAOSTAT, (2019). FAO Statistics Database. Food and Agriculture Organization of the United Nations. Retrieved April 24, 2019 from http://www. fao.org/faostat/en/\#data/QC/visualize

Ganie, S. A., Ghani, M. Y., Nissar, Q.\&Rehman, S. (2013). Bioefficacy of plant extracts and biocontrol agents against Alternaria solani. African Journal of Microbiology Research, 7(34), 4397-4402.

Gautam, S., Mahat, M., Manandhar H. K.\& Shrestha, S. M. (2018). Efficacy of chemical, botanical and biological for the management of Alternaria leaf spot of radish. Research Journal of Agriculture and Forestry Science, 6(8), 1-6.

Hajieghrari, B., Torabi-Giglou, M., Mohammadi, M. R. \&Devari, M. (2008). Biological potential of some Iranian Trichoderma isolates in the control of soil borne plant pathogenic fungi. African Journal of Biotechnology, 7(8), 967-972.

Kakraliya, S. S., Choskit, D., Pandit, D.\&Abrol, S. (2018). Effect of bio-agents, neem leaf extract and fungicides against Alternaria leaf blight of wheat (Triticum aestivum L.). International Journal of Advanced Biological and Biomedical Research 7(1), 23-24.doi: 10.18869/IJABBR.2018.23

Kantwa S. L., Tetarwal, J. P. \&Shekhawat, K. S. (2014). In vitro effect of fungicides and phyto-extracts against Alternaria alternata causing leaf blight of groundnut. IOSR Journal of Agriculture and Veterinary Science, 7(6), 28-31.

Kavita\&Dalbeer. (2015). Efficacy of different botanicals against Alternaria brassicae in in vitro condition. International Journal of Science and Research (IJSR).

Khalse, K. D., Lal, A. A. \&Simon, S. (2017). Efficacy of bio-agents and plant extracts against the alternaria leaf spot of cabbage (Alternaria 
brassicae). Journal of Pharmacognosy and Phytochemistry, 6(4), 1980-1982

Kithan, C \&Daiho, L.(2014). In vitro evaluation of botanicals, bio-agents and fungicides against leaf blight of Etlingeralinguiformiscaused by Curvularia lunatavar. aeria. Journal of Plant Pathology and Microbiology, 5: 3. doi: http:// dx.doi.org/10.4172/2157-7471.1000232

Kumar, K., Amarosan, N., Bhagat, S., Madhuri, K., Udhayaraj, P. \&Srivastava, R. C. (2011). Genetic and physioilogical relatedness of antagonistic Trichoderma isolates against soil borne plant pathogenic fungi. Archives of Phytopathology and Plant Protection, 44 (14),1399-1409.

Kutawa, A. B., Danladi, M. D. \&Haruna, A. (2018). Antifungal activity of garlic (Alliumsativum) extract on some selected fungi. Journal of Medicinal Herbs and Ethnomedicine 4, 12-14

Lyer, S. R., Williamson, D.(1991). Efficacy of some plant extracts to inhibit the protease activity of Trichophyton species GeobiosTadhpur, 8(1), 3-6.

Madalagi, A. A., Kulkarni, M. S., Koulagi, S., Kulkarni, B. S. \&Naik, R. B. (2014). In vitro evaluation of fungicides, botanicals and bio agents against Alternaria alternata causing leaf spot disease in Chrysanthemum. The Journal of Floriculture, 2(1): 39-43.

Mamgain, A., Roychowdhury, R. andTah, J.(2013). Alternaria pathogenicity and its strategic controls. Research Journal of Biology, 1: 01-09.

MOAD, Nepal(2018). Statistical information on Nepalese agriculture 2016/17. Retrieved on April 242019 from https://nepalindata.com/ resource/statistical-information-nepaleseagriculture-207374-201617/.

Muhamad, H., Zainol, M. \&Sahid, I. (2010). Determination of hexaconazole in field samples using gas chromatography -electron capture detection (GC-ECD). Retrieved from http:// palmoilis.mpob.gov.my/publications/TOT/TS79,80\&81.pdf

Mungkornasawakul, P., Supyen, D., Jatisatienr, C., Jatisatienr, A. and Dheeranupattana, S. (2002). Inhibitory effect of Acorus calamusl. extract on some plant pathogenic molds. Proceeding of International Conference on MAP.

Nene, Y.L.\&Thapliyal, P.N. (1979).Fungicides in plant disease control. New Delhi: Oxford and JBH $413 \mathrm{p}$
Panwar V., Yadav, R. S., Singh, H.\&Shukla, A.C. (2013). In vitro evaluation of fungicides and bio agents against Alternaria alternata - an incident of leaf spot of Aloe vera.

Patel, M. D., Lal, A. A. \& Singh, P. P.(2014). Efficacy of certain bio agents and fungicides against root rot of Chilli (Capsicum annum L.). Supplement on Plant Pathology, 9(3), 1273-1277.

Phongpaichit, S., Pujenjob, N., Rukachaisirikul, V. \&Ongsakul, M.(2005). Antimicrobial activities of the crude methanol extract of Acorus calamus Linn. Journal of Science and Technology, 27(Suppl. 2), 517-523

Pitipong, T. (2009). Implementation of bio-fungicides and seed treatment in organic Rice cv. Kdml 105 farming.Pakistan Journal of Biological Sciences, 12 , 1119-1126.doi: $\underline{10.3923 /}$ pjbs.2009.1119.1126.

Polaquini, S. R., Svidziniski, T. I., Kemmelmeier, C. \&Gasparetto, A. (2006). Effect of aqueous extract from neem (Azadirachta indicaA. Juss) on hydrophobicity, biofilm formation and adhesion in composite resin by Candida albicans. Archives of Oral Biology, 51(6), 482490.

Roopa, R. S., Yadahalli, K. B. \&Kavyashree, M. C. (2014). Evaluation of natural plant extracts, antagonists and fungicides against early blight caused by $A$. solani in vitro. An International Quaterly Journal of Life Sciences, 9(3), 13091312.

Sadana, D. and Didwania, N. (2015). Bioefficacy of fungicides and plant extracts against Alternaria solani causing early blight of tomato. International Conference on Plant, Marine and Environment Sciences.

Saharan, G. C., Mehta, N. \&Meena, P. D. (2016). Alternaria Diseases of Crucifers: Biology, Ecology and Disease Management.Singapore: Springer Science + Business Media Singapore, pp: 59-61. doi: 10.1007/978-981-10-0021-8

Shrestha A. K. \&Tiwari, R. D. (2009). Antifungal activity of crude extracts of some medicinal plants against Fusarium solani (mart.) sacc. Ecological Society (ECOS), Nepal, 15, 75-78

Shrestha S.K., Munk, L.\&Mathur, S. B. (2005). Role of weather on Alternaria leaf blight disease and its effect on yield and yield component of mustard. Nepal Agric Res J 6, 62-72 
Singh, B. R., Singh, V., Singh, R. K., Toppo, S., Haque, N. \&Ebibeni, N. (2011). Antimicrobial effect of Artemisia vulgaris essential oil. ICAR Research Complex for NEH Region, Jharnapani, Nagaland (INDIA).

Singh, D. K. (2007). Modern Vegetable Varieties and Production Technology, pp. 171-172. Lucknow, India: International Book Distributing Co.

Singh, H. K., Singh, R. B., Kumar, P., Singh, M., Yadav, J. K., Singh, P. K., Chauhan, M. P., Shakywar, R. C., Maurya, K. N., Priyanka, B. S., Srivastava, T., Yadav, S. K. \&Maurya, M. K. (2017). Alternaria blight of rapeseed mustarda review. Journal of Environmental Biology, 38, 1405-1420. doi: http://doi.org/10.22438/ $\mathrm{jeb} / 38 / 6 / \mathrm{MS}-248$

Singh, R. S. (1998). Plant Diseases( $7^{\text {th }}$ ed). New Delhi: Oxford and IBH

Thaware, D. S., Fugro, P. A., Jadhav, Y. T., Magar, S. V. \&Karande, R. A. (2010). In vitro evaluation of different fungicides, plant extracts and bioagents against Alternariaalternata(Fr.) Keissler causing leaf blight of cowpea. International Journal of Plant Protection, 3(2), 356-360.

Tu, V.D., (2015).Studies on Alternaria leaf $\operatorname{spot}$ (Alternariabrassicicola(Schw.) Wiltshire) of cabbage (Brassica oleraceavar. capitataL.). Ph.D. Thesis (Unpublished), University of Agricultural Sciences, Bengaluru

Ul-Haq, S., Hasan, S. S., Dhar, A., Mital, V. \&Sahaf, K. A. (2014). Antifungal properties of phytoextracts of certain medicinal plants against leaf spot of disease of Mulberry, Morusspp. Plant Pathology and Microbiology, 5(2). Retrieved fromhttp:// dx.doi.org/10.4172/2157-7471.1000224

Vincent, J. M., (1947), Distribution of fungal hyphae in the presence of certain inhibitors. Nature,159: 850 .

Waghe, K.P., Wagh, S. S., Kuldhar, D. P. \&Pawar, D.V. (2015). Evaluation of different fungicides, bioagents and botanicals against Alternaria blight caused by Alternaria helianthi (Hansf) sunflower. African Journal of Agricultural Research, 10(5), 351-358.

Yu, S. H. (2015). Fungal Flora of Korea. Chungnam National University. Korea: Kim, Sang-Bae,1(2). 